\title{
PEMODELAN ANTRIAN SISTEM PENGAMBILAN PESANAN PRODUK PADA GUDANG MINUMAN RINGAN DENGAN SISTEM RAK DRIVE-IN
}

\section{A QUEUE MODELLING OF ORDER PICKING SYSTEM IN BEVERAGES WAREHOUSING WITH DRIVE-IN RACK SYSTEM}

\author{
M Zaky Hadi ${ }^{1 *}$, Taufik Djatna ${ }^{2)}$, dan Sugiarto ${ }^{2)}$ \\ ${ }^{1)}$ Program Studi Teknologi Industri Pertanian, Fakultas Teknologi Pertanian, Institut Pertanian Bogor \\ Kampus IPB Darmaga, Bogor 16680, Jawa Barat, Indonesia \\ E-mail: zaky_hadi@apps.ipb.ac.id \\ ${ }^{2}$ Departemen Teknologi Industri Pertanian, Fakultas Teknologi Pertanian, Institut Pertanian Bogor \\ Makalah: Diterima 31 Juli 2017; Diperbaiki 20 November Juli 2017; Disetujui 2 Desember 2017
}

\begin{abstract}
This paper proposed a queue model for beverage order picking system produced from agricultural commodity in warehouse with drive-in rack system in order to analyze and increase the warehouse performance. A $(M / M / C):(G D / N / \infty)$ queue approach was used to build the model with the queue approach. This paper considered total operator must-be-assigned to improve queue time (Wq), queue length, and utilization in the warehouse. Stack, queue, linked list, Colour HSB (Hue, Saturation, Brightness) algorithms were used to represent drive-in rack, product queuing, and product status in the warehouses. The model was implemented in computer simulation using java programming. After build the model, a real case industrial problem was presented to test the model. The model could calculate warehouse performance including low performance in racking, transportation to loading area, and loading process for current number of operators and idle operator in the warehouse process. This result was in line with the industry condition that has over capacity and high product bottlenecks in the warehouse. The model was used to find and analyze total operator-must-assigned to increase the warehouse performance. The computer simulation showed colour changing based on density of product stack in queue area. This colour degradation helped for easier understanding and accelerating product status detection (including hold, ready-to-release, and expired beverage products in the warehouse).
\end{abstract}

Keywords:beverage warehousing, drive-in rack, order picking, queue modelling, queueing theory

\section{ABSTRAK}

Paper ini mengusulkan model antrian untuk sistem pengambilan pesanan produk-produk minuman ringan dengan studi kasus minuman ringan hasil olahan komoditas pertanian yang memiliki Batasan umur simpan pada gudang dengan sistem rak drive-in dalam rangka menganalisis dan meningkatkan kinerja

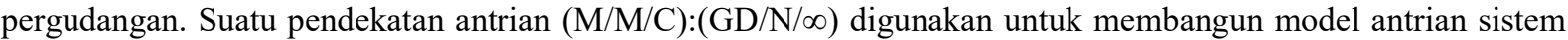
pengambilan pesanan produk minuman ringan tersebut. Paper ini mempertimbangkan total operator yang harus ditugaskan untuk memperbaiki waktu antrian, panjang antrian, dan utilisasi pada gudang berdasarkan pendekatan antrian yang digunakan. Algoritma tumpukan, antrian, linkedlist, pewarnaan HSB (Hue, Saturation, Brightness) digunakan untuk merepresentasikan rak drive-in, antrian produk, dan status produk pada gudang. Selanjutnya, model antrian tesebut diimplementasikan pada simulasi komputer menggunakan bahasa pemrograman java. Suatu studi kasus masalah industri nyata disajikan untuk menguji model yang dibangun. Berdasarkan studi kasus tersebut, model yang dibangun dapat menentukan kinerja gudang meliputi rendahnya kinerja pada proses racking, transportasi produk menuju area pembongkaran, dan proses pembongkaran produk untuk sejumlah operator yang saat ini ditugaskan serta adanya operator menganggur pada proses di gudang. Hasil dari model untuk studi kasus sesuai dengan hasil observasi kondisi gudang industri tersebut yang saat ini mengalami kelebihan kapasitas serta bottleneck yang tinggi. Selanjutnya model tersebut digunakan untuk menentukan dan menganalisis jumlah operator yang harus ditugaskan untuk meningkatkan kinerja gudang. Simulasi komputer memperlihatkan aliran warna sesuai dengan kerapatan dan tumpukan produk pada area antrian. Degradasi warna ini membantu pemahaman yang lebih mudah dan peningkatan deteksi status produk pada gudang (meliputi produk yang harus ditahan, siap untuk dirilis, dan produk kadaluarsa di gudang).

Kata kunci : pemodelan antrian, teori antrian, pergudangan minuman ringan, rak drive-in, sistem pengambilan pesanan produk

\section{PENDAHULUAN}

Sistem pengambilan pesanan produk (order picking system) adalah suatu sistem operasional pergudangan yang berkaitan dengan proses mengambil dan mengeluarkan produk dari area penyimpanan sebagai respon untuk memenuhi permintaan yang datang dari aktor selanjutnya (next sphere) pada suatu rantai pasok (order) maupun 
permintaan (demand) dari konsumen akhir (Petersen dan Schmenner, 1999; De Koster et al., 2007). Sistem ini sangat penting dipertimbangkan karena pergudangan dan inventori merupakan salah satu penggerak (driver) yang cukup penting untuk menjamin jalannya arus barang pada sistem logistik secara responsif dan efisien. Proses pada sistem ini meliputi pengelompokkan dan penjadwalan pesanan dari konsumen, pengalokasian stok sesuai pesanan produk, menurunkan produk dari rak ke lantai gudang, mengambil produk dari area penyimpanan serta pemisahan produk-produk yang telah diambil (De Koster et al., 2007).

Tujuan paling umum dari order picking system adalah untuk memaksimasi level layanan dengan batasan sumberdaya seperti ketersedian tenaga kerja, mesin, area, jumlah gudang dan biaya pergudangan (Goetschalckx dan Ashayeri, 1989). Sistem operasional ini penting dipertimbangkan karena kedatangan produk (dari departemen produksi atau dari supplier) biasanya diterima dan disimpan dalam jumlah unit volume yang besar sedangkan konsumen biasanya memesan dalam jumlah unit yang lebih kecil dengan beragam tipe produk. Pesanan konsumen yang datang pada suatu gudang biasanya terdiri dan dikelompokkan dalam jalur-jalur pasanan dimana setiap jalur pesanan memiliki produk-produk tertentu yang unik dan spesifik atau dalam bentuk stock keeping unit (SKU).

Order picking teridentifikasi sebagai aktivitas yang paling penting dan memiliki prioritas yang paling tinggi dalam suatu pergudangan untuk memperbaiki produktivitas karena mengkonsumsi biaya pergudangan tertinggi dibandingkan sistem dan proses-proses lainnya (lihat De Koster et al., 2007; Tomkins, 2003; Gademann dan Van de Velde, 2005). Sebagian besar elemen-elemen kerja Order Picking meliputi perjalanan menuju area penyimpanan produk, mencari produk yang akan diambil, mengambil dan membongkar tumpukan produk dari area penyimpanan, pendokumentasian artikel yang diambil dan pengurutan produk sesuai pesanan (Parikh dan Meller, 2007).

Salah satu masalah dan tantangan sistem pengambilan pesanan produk adalah penyimpanan produk-produk minuman ringan hasil olahan pertanian terkemas yang memiliki batasan umur simpan yang terbatas serta tipe rak drive-in yang memiliki sistem alokasi dan pengambilan berbentuk last-in-first-out (LIFO). Kompleksitas LIFO dan umur simpan ini menyebabkan banyaknya industri minuman ringan terutama industri minuman ringan olahan hasil komoditas pertanian yang menggunakan sistem rak drive-in mengalami kelebihan kapasitas dan tingginya kadaluarsa produk. Murahnya biaya instalasi rak serta dapat menyimpan produk dengan jumlah yang lebih besar dibandingkan dengan tipe rak lainnya menjadikan banyak pergudangan industri menggunakan sistem rak ini.
Riset-riset mengenai sistem pengambilan sistem pesanan produk khusus untuk bentuk gudang tertentu telah banyak dilakukan. Pan et al.(2016) mengembangkan model optimasi dan antrian pada sistem gudang pick-and-pass. Berglund dan Batta (2012) mengembangkan alokasi penyimpanan untuk gudang dengan tipe operasi Picker-to-Parts. Yang et al.(2015) mengembangkan alokasi penyimpanan dan pengambilan produk pada gudang dengan sistem shared-storage dan alokasi penyimpananpengambilan multi-shuttle. Namun semua riset tentang operasional penggudangan tesebut tidak mempertimbangkan rak tiga dimensi (Drive-in, Drive-Thru dan sebagainya) sifat produk seperti batasan umur simpan pada produk olahan pertanian.

Riset ini mengembangkan model dasar berbasis komputer untuk sistem pengambilan pesanan produk pada gudang dengan sistem rak drive-in. Pendekatan yang digunakan berbasis teori antrian dan algoritma-algoritma untuk merepresentasikan operasional dan fisik rak drive-in. Studi kasus pada suatu gudang minuman ringan olahan komoditas pertanian terkemas (PT X) digunakan untuk menguji model. Produk ini terdiri dari minuman teh terkemas, kopi, jeli, dan olahan susu. Riset ini sangat penting dikarenakan belum adanya pengembangan model sistem rak Drive-in dan banyaknya industri pangan terkemas yang menggunakan tipe rak ini.

Paper ini disusun dari beberapa bagian. Bagian pertama disajikan metode riset pemodelan yang meliputi formulasi model antrian produk minuman ringan dengan model $(\mathrm{M} / \mathrm{M} / \mathrm{C}):(\mathrm{GD} / \mathrm{N} / \infty)$ untuk penentuan jumlah operator. Selanjutnya algoritma tumpukan, antrian, linkedlist, pewarnaan HSB (hue, saturation, brightness) digunakan untuk memodelkan rak Drive-in, antrian produk, dan status produk minuman ringan pada gudang. Formulasi antrian produk dan algoritma-algoritma tersebut diimplementasikan dalam bentuk simulasi komputer untuk mempermudah proses analisis. Suatu studi kasus gudang industri digunakan untuk menguji model yang telah dibangun. Bagian kedua disajikan model berbasis komputer dan hasil dan studi kasus dari gudang industri minuman ringan olahan komoditas pertanian yang terdiri dari teh, kopi dan susu terkemas PET dan ditumpuk diatas pallet. Bagian ketiga disajikan kesimpulan dan riset-riset lanjutan.

\section{METODE PENELITIAN}

Kerangka kerja pemodelan ini terbagi atas tiga. Bagian pertama adalah observasi awal untuk melihat kondisi gudang secara nyata serta untuk mengumpulkan data awal pada gudang yang akan dijadikan sampel. Selanjutnya bagian kedua, dikembangkan model sistem pengambilan pesanan produk minuman ringan menggunakan konsep

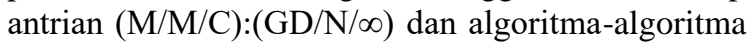


untuk merepresentasikan sistem rak drive-in. Bagian ketiga prototipe model antrian berbasis komputer diujicobakan pada studi kasus yang dikaji. Tahapan tersebut direpresentasikan pada Gambar 1.

Rancangan Jumlah Operator Penanganan Bahan Berdasarkan Performansi Antrian Menggunakan Model Antrian $(M / M / c):(G D / N / \infty)$

Model antrian pada penelitian ini menggunakan model $(M / M / c)$ : $(G D / N / \infty)$ berdasarkan perhitungan distribusi data tipe diskrit, area antrian dan jumlah operator terbatas. Menurut Taha (2007) kedatangan dan keberangkatan produk didefinisikan sebagai berikut:

$\lambda_{n}=\left\{\begin{array}{lr}\lambda, & 0 \leq n \leq N \\ 0, & n>N\end{array}\right.$

$\mu_{n}= \begin{cases}\mu n, & 0 \leq n \leq c \\ c \mu, & c \leq n \leq N\end{cases}$

dimana

$\lambda$ : Tingkat kedatangan produk ke dalam sistem $\boldsymbol{\mu}:$ Tingkat kepergian produk dari sistem

$n$ : Jumlah produk berada dalam sistem

$N$ : Jumlah maksimal produk yang diizinkan berada dalam sistem

Perhitungan performansi antrian $(M / M / c)$ : $(G D / N / \infty)$ pada gudang finish good meliputi perkiraan banyak produk menunggu pada antrian, perkiraan lama waktu menunggu produk pada area antrian, operator sibuk dan utilitas dengan asumsi kedatangan dan servis produk mengikuti distribusi Poisson.

\section{Formulasi Perkiraan Banyak Produk Menunggu pada Antrian}

Menurt Bhat (2008) rasio antara tingkat kedatangan (arrival rate) dan pelayanan (service rate) memainkan peranan penting dalam pengukuran performansi sistem antrian. Rasio ini disebut intensitas lalu lintas produk dalam sistem (traffic intensity) yang didefinisikan sebagai perbandingan tingkat kedatangan dengan tingkat pelayanan. Traffic intensity disebut juga utilitas aliran produk dalam sistem (utilization of each runaway).

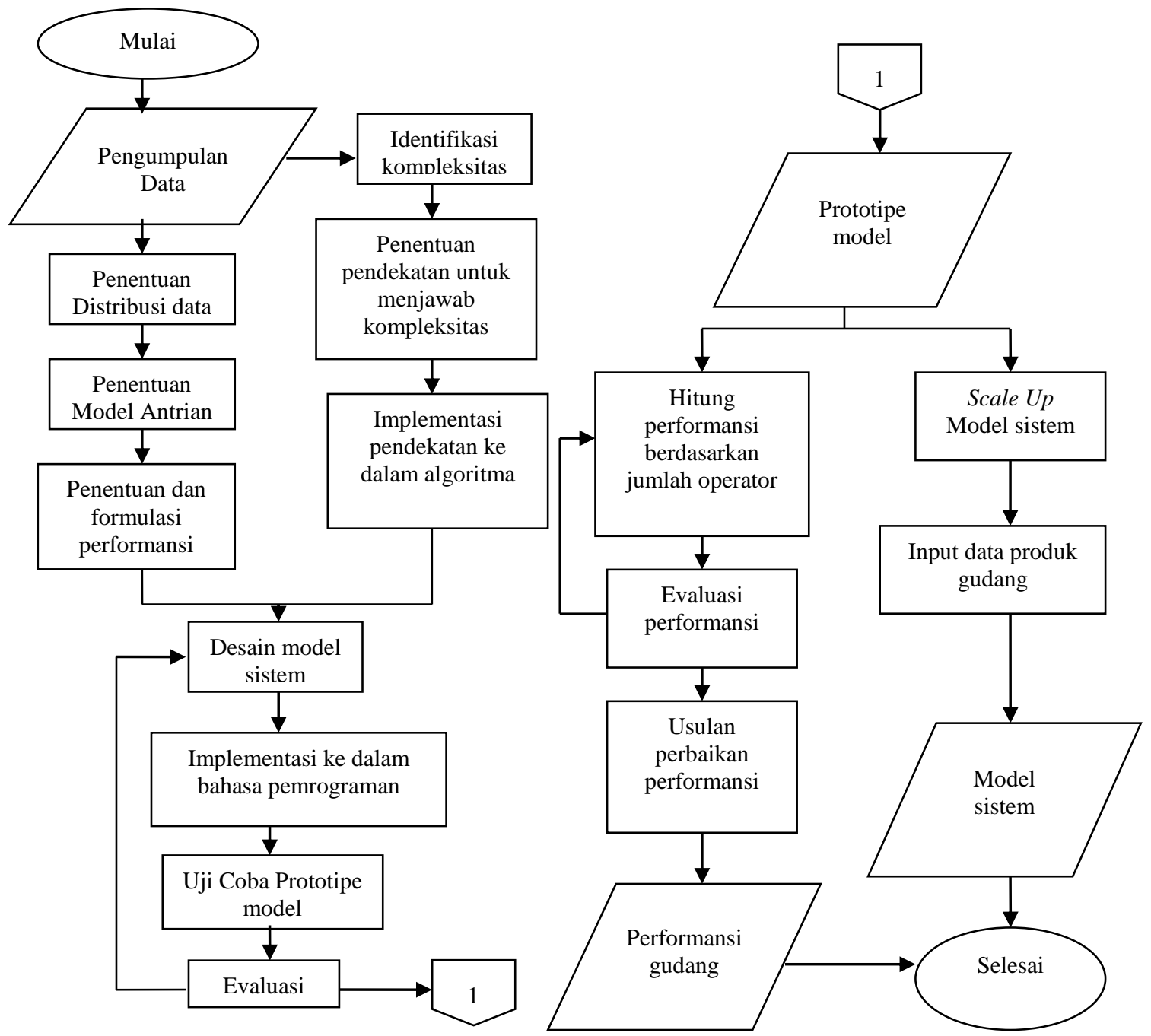

Gambar 1. Kerangka kerja riset 
Utilitas aliran produk dalam sistem padamodel antrian $(M / M / C)$ dengan area antrian terbatas berlaku untuk setiap c server pada sistem antrian sehingga formulasinya traffic intensity berlaku untuk setiap c operator. Menurut Taha (2007) antrian dengan model $(M / M / c)$ memiliki dua kondisi berbeda yaitu kondisi $\rho / \mathrm{c}=1$ dan kondisi $\boldsymbol{\rho} / \mathrm{c} \neq 1$ dengan formulasi perkiraan banyak produk menunggu pada antrian masing-masing kondisi didefinisikan sebagai berikut:

$P_{n}= \begin{cases}\frac{\rho^{n}}{n !} P o, & 0 \leq n \leq c \\ \frac{\rho^{n}}{c ! c^{n-c}} P o, & c \leq n \leq N\end{cases}$

dimana $P o$ merupakan probabilitas adanya produk sebanyak 0 (tidak adanya produk) dalam sistem. $P o$ didefinisikan sebagai berikut:

$P_{O}=\left\{\begin{array}{l}\left(\sum_{n=0}^{c-1} \frac{\rho^{n}}{n !}+\frac{\rho^{c}\left(1-\left(\frac{\rho}{c}\right)^{N-c+1}\right)}{c !\left(1-\frac{\rho}{c}\right)}\right)^{-1}, \frac{\rho}{c} \neq 1 \\ \left(\sum_{n=0}^{c-1} \frac{\rho^{n}}{n !}+\frac{\rho^{c}}{c !}(N-c+1)\right)^{-1}, \frac{\rho}{c}=1\end{array}\right.$

Keterangan :

$L_{q} \quad$ : Perkiraan banyak produk menunggu pada area antrian

$N$ : Jumlah maksimal produk yang diizinkan berada dalam sistem

$n \quad$ : Jumlah produk berada dalam sistem

c : Jumlah operator

$P_{n}$ : Probabilitas kondisi steady-state $\mathrm{n}$ produk berada dalam sistem

Po : Probabilitas tidak ada produk dalam sistem

$\boldsymbol{\rho} \quad$ : Traffic Intensity

Formulasi Perkiraan Lama Waktu Menunggu Produk pada Area Antrian

Menurut Taha (2007) perkiraan lama waktu menunggu produk dipengaruhi oleh kedatangan efektif produk ke dalam sistem. Kedatangan efektif didefinisikan sebagai produk yang datang kedalam sistem saat kapasitas antrian mencukupi. Kedatangan efektif diperoleh dari selisih antara tingkat kedatangan dengan tingkat pelayanan produk yang tidak dapat masuk ke dalam sistem. Tingkat kedatangan produk yang tidak dapat masuk ke dalam sistem diperoleh dari perkalian antara tingkat kedatangan dengan probabilitas $\mathrm{N}$ pelanggan berada dalam sistem. Perkiraan lama waktu menunggu produk pada area antrian dihitung berdasarkan formula Little's dengan formulasi sebagai berikut :

$L_{s}=\lambda_{\text {eff }} W_{s}$

$L_{q}=\lambda_{e f f} W_{q}$

$\lambda_{\text {eff }}=\lambda-\lambda_{\text {lost }}=\left(1-P_{N}\right) \lambda$

$\lambda_{\text {lost }}=\lambda P_{N}$

$$
\begin{array}{lll}
L_{s} & : & \begin{array}{l}
\text { Perkiraan banyak produk menunggu } \\
\text { pada sistem }
\end{array} \\
L_{q} & : & \begin{array}{l}
\text { Perkiraan banyak produk menunggu } \\
\text { pada area antrian }
\end{array} \\
\lambda_{\text {eff }} & : & \begin{array}{l}
\text { Tingkat kedatangan efektif produk ke } \\
\text { dalam sistem }
\end{array} \\
W_{s} & : & \begin{array}{l}
\text { Perkiraan waktu menunggu produk } \\
\text { dalam sistem }
\end{array} \\
W_{q} & : & \begin{array}{l}
\text { Perkiraan waktu menunggu produk } \\
\text { dalam antrian }
\end{array} \\
\lambda_{\text {lost }} \quad: \quad \begin{array}{l}
\text { Tingkat kedatangan produk yang tidak } \\
\text { dapat masuk ke dalam sistem }
\end{array} \\
\mathrm{N} & : \quad \begin{array}{l}
\text { kapasitas maksimum area antrian } \\
\end{array}
\end{array}
$$

\section{Formulasi Rata-Rata Jumlah Operator Sibuk}

Menurut Taha (2007) selisih antara perkiraan jumlah produk dalam sistem dengan jumlah produk dalam area antrian didefinisikan sebagai rata-rata jumlah operator sibuk. Formulasi rata-rata jumlah operator sibuk didefinisikan sebagai berikut:

$\bar{c}=L s-L q=\lambda_{e f f} / \mu$

Dimana :

$\bar{c} \quad: \quad$ Rata-rata jumlah operator sibuk dalam sistem

Ls : Perkiraan banyak produk menunggu pada sistem

$L q \quad$ : Perkiraan banyak produk menunggu pada area antrian

$\lambda_{\text {eff }}:$ Tingkat kedatangan efektif produk ke dalam sistem

$\boldsymbol{\mu} \quad$ : Tingkat kepergian produk dari sistem

\section{Utilitas Operator}

Utilitas operator merupakan perbandingan antara operator sibuk dengan jumlah operator maksimum. Utilitas operator digunakan untuk mengetahui persentase operator sibuk dengan server menganggur. Formulasi utilitas operator didefinisikan sebagai berikut:

Utilitas $=\bar{c} / c$

Dimana

$\bar{c} \quad$ : Rata-rata jumlah operator sibuk dalam sistem

$c$ : Jumlah operator maksimum

\section{KonsepAlgoritma Tumpukan (Stack)}

Konsep tumpukan digunakan untuk merepresentasikan kompleksitas sistem rak drive-in. Aturan pada konsep ini adalah setiap produk yang datang terakhir akan dieksekusi pertama atau last in first out (LIFO). Rak drive-in adalah rak yang memiliki satu jalan masuk sekaligus sebagai jalan keluar. Material yang disimpan pada rak ini memiliki aturan LIFO. Model rak drive-in diilustrasikan pada Gambar 2.

Dimana: 


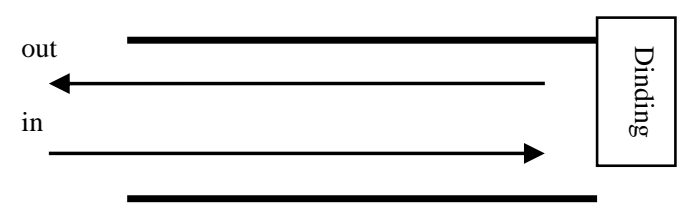

Gambar 2. Ilustrasi model rak Drive-in

Konsep tumpukan direpresentasikan dalam bentuk algoritma tumpukan. Algoritma tumpukan adalah salah satu algoritma struktur atau himpunan data pada Array yang mengimplementasikan aturan LIFO. Operasi Insert pada algoritma tumpukan biasanya disebut Push, dan operasi Delete disebut Pop. Menurut Cormen et al. (2009) model algoritma tumpukan digambarkan pada Gambar 3.

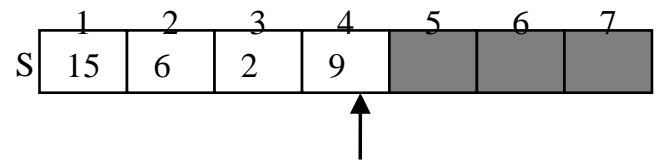

S.top $=4$

(a)

\begin{tabular}{c|c|c|c|c|c|c|}
\hline & \multicolumn{1}{c}{2} & 3 & 4 & 5 & 6 & 7 \\
\hline 15 & 6 & 2 & 9 & 17 & 3 & \\
\hline & \multicolumn{5}{c}{$\left.\right|_{\text {S.top }=6}$}
\end{tabular}

(b)

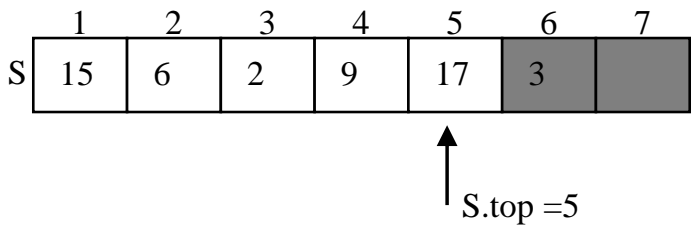

(c)

Gambar 3. Ilustrasi model algoritma tumpukan pada struktur data

Elemen paling atas (S.top) pada tumpukan $\mathrm{S}$ adalah angka 9. Setelah dilakukan penambahan data 17 dan 3 pada tumpukan, elemen paling atas pada tumpukan S adalah angka 3 (Gambar 3.b). Jika angka 3 pada tumpukan paling atas diambil maka elemen paling atas tumpukan adalah angka 17 (Gambar 3.c). Menurut Cormen et al. (2009) operasi tumpukan pada setiap gambar diatas dapat diimplementasikan kedalam beberapa baris kode sebagai berikut:

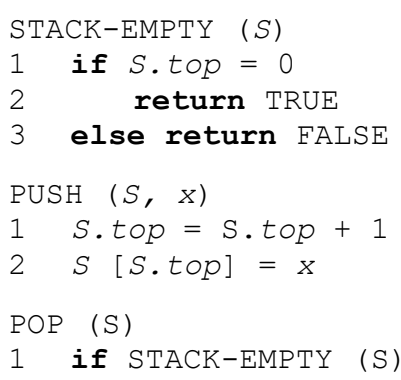

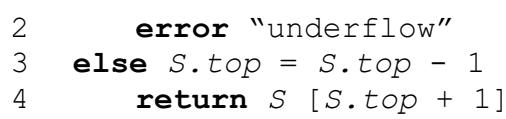

\section{Konsep AlgoritmaAntrian (Queue)}

Konsep antrian digunakan untuk merepresentasikan kompleksitas disiplin antrian (FIFO) pengambilan dan operasional pergudangan produk pada gudang.Konsep ini direpresentasikan dalam bentuk algoritma antrian. Algoritma antrian adalah salah satu algoritma struktur atau himpunan data pada Array yang mengimplementasikan aturan FIFO. Operasi Insert pada algoritma antrian disebut Enqueue dan operasi Delete disebut Dequeue. Algoritma antrian memiliki bagian kepala (head) dan ekor (Tail). Ketika elemen data disisipkan (Enqueue) maka data akan menempati bagian ekor dari antrian sedangkan elemen data dihapus (Dequeue) selalu pada bagian kepala. Menurut Cormen et al. (2009) model algoritma antrian digambarkan pada gambar 4.

Gambar 4 menjelaskan suatu susunan (array) S yang memiliki 12 penempatan data. Susunan data awal memperlihatkan bagian kepala (Q.head) terletak pada posisi ke 7 dan bagian ekor (Q.tail) pada posisi ke 12 (Gambar 4.a). Setelah disisipkan data pada posisi ke 12,1, dan 2 bagian kepala tetap pada posisi ke 7 dan bagian ekor berada pada posisi ke 3 (Gambar 4.b). Data diambil pada bagian kepala (posisi 7) sehingga bagian kepala selanjutnya berada pada posisi ke 8. Menurut Cormen et al. (2009) algoritma antrian dapat diimplementasikan kedalam beberapa baris kode sebagai berikut:

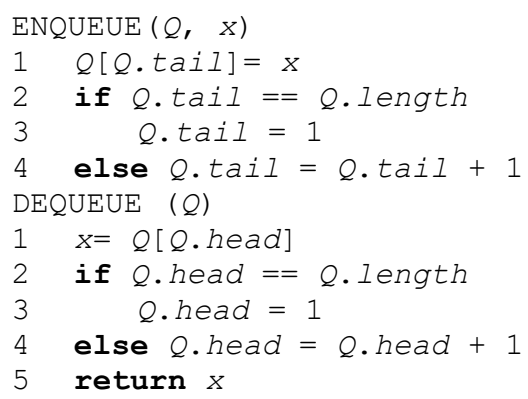

Algoritma antrian tersebut dikombinasikan dengan algoritma LinkedList karena setiap data pada setiap algoritma antrian memiliki status sebagai sucessor dan predecessor. Algoritma Linked List yang digunakan adalah doubly linked list yang digambarkan pada gambar 5 .

Gambar 5 (a) menjelaskan algoritma Doubly Linked List. Setiap elemen dalam susunan algoritma memiliki atribut-atribut dengan elemen kunci dan pointers yang terdiri dari next dan previous. Atribut next pada bagian ekor dan atribut prev pada bagian kepala bernilai Nil. Jika disisipkan atribut baru pada bagian kepala (angka 7) maka L.Head akan berada pada atribut baru tersebut (Gambar 5b), sedangkan jika diambil pada bagian ekor (angka 1) maka ekor akan menjadi angka 4. 


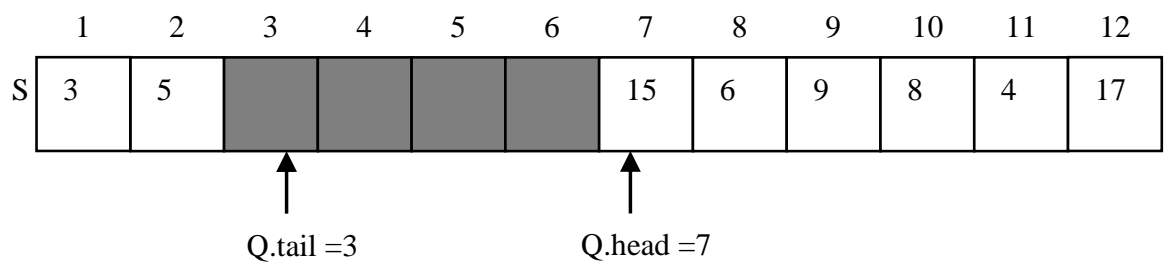

(a)

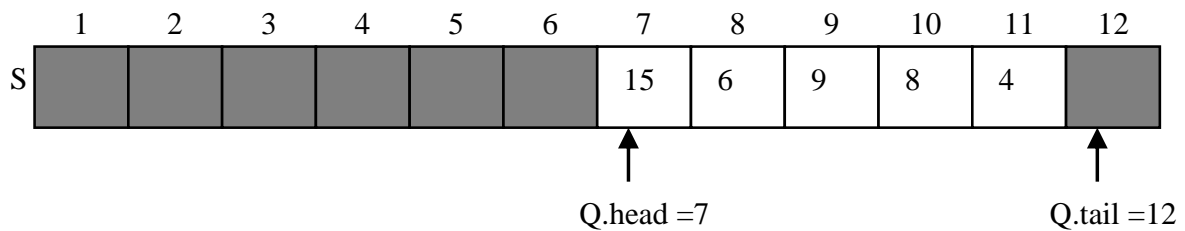

(b)

\begin{tabular}{|c|c|c|c|c|c|c|c|c|c|c|c|}
\hline 1 & 2 & 3 & 4 & 5 & 6 & 7 & 8 & 9 & 10 & 11 & 12 \\
\hline $\begin{array}{l}5 \\
5\end{array}$ & 5 & & & & & 15 & 6 & 9 & 8 & 4 & 17 \\
\hline
\end{tabular}

(c)

Gambar 4. Ilustrasi model algoritma antrian pada struktur model

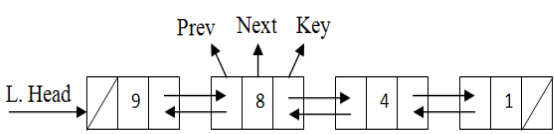

(a)

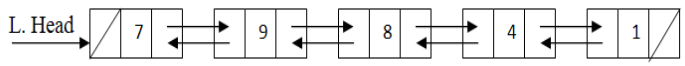

(b)

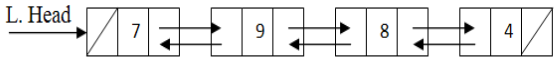

(c)

Gambar 5. Ilustrasi model algortima Doubly Linked List

\section{Konsep Color HSB (Hue, Saturation, Brightness)}

Konsep Color HSB (hue, saturation, brightness) digunakan untuk merepresentasikan tumpukan produk pada model sistem pergudangan dengan status warna hijau $(\mathrm{H}=0,30)$ jika produk kosong dan merah $(\mathrm{H}=0,00)$ jika tumpukan produk penuh pada area rak. Selain itu pewarnaan ini juga digunakan untuk mempermudah mendeteksi status kadaluarsa pada rak Drive-in.

\section{Implementasi ke dalam Bahasa Pemrograman Java}

Keempat perhitungan performansi antrian tersebut dikodekan kedalam bahasa pemrograman java dengan bantuan Java Modelling Tools Library (Bertolli et al., 2009). Impelementasi ini bertujuan untuk membangun model berbasis komputer. Model berbasis komputer ini selanjutnya digunakan untuk simulasi studi kasus. Java Modelling Tools library adalah framework lengkap untuk membantu evaluasi performansi sistem, perencanaan kapasitas, dan studi karakterisasi beban kerja. Framework ini ditulis dalam bahasa pemrograman java yang terdiri dari enam fitur yaitu:

1. JSIMgraph, yaitu Simulator model antrian dengan graphical user interface

2. JSIMwiz, yaitu Simulator model antrian denganwizard-based user interface

3. JMVA yaitu Analisis nilai rata-rata model antrian

4. JABA, yaitu Analisis asimtot model antrian

5. JWAT, yaitu Analisis beban kerja dari $\log$ dan data yang digunakan sistem

6. JMCH, yaitu Simulator Markov chain

Konsep pewarnaan direpresentasikan dalam bentuk algoritma warna pada pemrograman java. Pemrograman java Color HSB merupakan pemrograman yang sudah tersedia sebagai Java SE (standar edition) dan merupakan bagian dari java abstract window toolkit (Java AWT). Formulasi aliran warna ini direpresentasikan pada Gambar 6.

$\begin{array}{ll}0.30 & 0.00\end{array}$

Gambar 6. Aliran warna hijau $(0,30)$ menuju merah $(0,00)$ pada Java Color HSB

\section{Alat Bantu Perancangan dan Implementasi Model}

Model dikembangkan menggunakan bahasa pemrograman Java dengan bantuan perangkat lunak komputer yaitu Netbeans IDE 7.3 untuk 
implementasi model kedalam bahasa pemrograman java (OC, 2013), Balsamiq Mockups untuk desain antar muka model sistem (BS, 2014), JODA Time Library untuk perhitungan waktu (Colebourne, 2014), Java Modelling Tools Library untuk evaluasi performansi sistem (Bertoli et al., 2009), XAMPP untuk pengolahan basis data (Seidler dan Vogelgesang, 2014).

\section{Studi Kasus pada Pergudangan Minuman Ringan Olahan Komoditas Pertanian Terkemas}

Produk minuman ringan yang digunakan sebagai kasus pada penelitian ini adalah produk minuman ringan hasil olahan komoditas pertanian terkemas PET dan ditumpuk diatas Pallet. Jenis produk minuman ringan adalah teh manis, kopi, dan olahan susu. Produk-produk olahan pertanian ini tentunya memiliki Batasan umur simpan. Proses pergudangan produk minuman ringan pada gudang finish good dilakukan dalam lima tahap yaitu serah terima produk antara pihak gudang dengan produksi, racking, produk Release, transportasi dari waiting lines 2 ke area loading, dan proses loading (bongkar palet). Proses ini dilakukan oleh departemen Supply Chain Management yang terdiri dari kepala gudang, team leader, dan operator gudang.

Proses serah terima dilakukan oleh admin gudang dengan admin produksi sesuai jumlah produk per palet dan setiap palet yang akan masuk gudang akan diberi status inkubasi (Pengecekan status kualitas produk oleh departemen quality control). Selanjutnya produk dibawa oleh operator hand palet ke area waiting lines 1. Status inkubasi ini berjalan selama delapan hari dengan hasil pengecekan diterima atau reject. Jumlah produk per palet adalah 132 kotak dengan jumlah produk masing-masing kotaknya adalah 24 cup. Produk dimuat ke palet oleh operator pengemas pada enam line produksi.

Proses racking dilakukan oleh operator forklift ke rak gudang finish good. Status produk pada rak adalah inkubasi atau release dengan kapasitas maksimal rak adalah 3000 posisi palet. Jenis rak pada proses racking adalah rak drive-in dengan instalasi rak permanen yang terbagi dalam delapan blok dengan kapasitas masing-masing blok yang berbeda-beda. Instalasi permanen pada rak drive-in gudang menyebabkan sulitnya pengaturan tata letak ulang dikarenakan faktor luas area pabrik dan biaya yang cukup besar.

Proses release (picking order) adalah proses penurunan produk dari rak dengan status produk diterima untuk selanjutnya dilakukan proses bongkar dari palet ke kontainer armada. Sebelum di muat ke armada, produk mengantri di area waiting lines 2 . Produk yang tidak lolos uji dan kadaluarsa akan diambil oleh operator forklift untuk dilakukan penghancuran produk dan proses treatment limbah. Tidak ada aturan rute atau scenario picking order pada proses release produk ini. Operator mengambil palet pada rak sesuai instruksi dari admin gudang.

Proses selanjutnya adalah transportasi yang dilakukan oleh operator hand palet dari area waiting lines 2 ke area loading. Setelah palet sampai pada area loading operator memindahkan produk dari palet ke kontainer armada.Produk dicatat oleh operator ekspedisi untuk selanjutnya dibuat surat jalan armada. Armada berkapasitas 4000 kotak produk, dan mentransportasikan produk ke gudang distributor untuk selanjutnya dikirim ke konsumen oleh pihak distributor.

\section{HASIL DAN PEMBAHASAN}

Tahapan implementasi model konseptual dilakukan dengan menerjemahkan formulasi dan algoritma pada analisis kompleksitas dan model antrian kedalam bahasa pemrograman java. Selanjutnya, hasil implementasi ini diuji coba meliputi debugging dan validasi dalam bentuk uji coba perhitungan dan representasi sistem pergudangan pada model. Uji coba perhitungan dilakukan dengan membandingkan hasil perhitungan model sistem dengan TORA (Taha, 2007). Uji coba representasi sistem pergudangan dilakukan dengan melihat status warna bottleneck, area antrian dan rak pada model sistem. Proses evaluasi dilakukan jika hasil uji coba sistem tidak valid. Tahapan scale up dilakukan untuk meningkatkan kapasistas model sistem menjadi 3000 posisi palet yang terdiri dari delapan blok rak. Tahapan selanjutnya pada pengembangan model ini adalah maintenance yang dilakukan dengan mengevaluasi bug pada model sistem kemudian memperbaikinya.

Hasil Perhitungan Performansi Antrian Produk untuk Jumlah Operator yang Ditugaskan Saat Ini (Current Operators) Sistem Pengambilan Pesanan Produk pada Studi Kasus

Tahapan awal perhitungan performansi antrian sistem pergudangan produk minuman ringan dilakukan setelah model selesai dievaluasi. Data yang dibutuhkan pada proses perhitungan performansi ini adalah kapasitas area antrian, jumlah kedatangan produk dan jumlah handling produk. Berdasarkan hasil observasi dan pengukuran langsung di gudang finish good didapatkan data ratarata kapasitas antrian produk, jumlah kedatangan produk dan jumlah handling produk untuk setiap prosesnya ditabulasikan pada Tabel 1.

Data ini akan menjadi inputan utama perhitungan performansi antrian pada model sistem pergudangan yang dirancang. Model sistem diberi nama Pineapple Logistic 1. Hasil perhitungan performansi antrian dengan jumlah operator awal yang ditugaskan oleh pihak gudang finish good menggunakan model sistem yang dirancang ditabulasikan pada Tabel 2. 
Tabel 1. Hasil pengukuran kedatangan dan handling produk gudang finish good

\begin{tabular}{|c|c|c|c|}
\hline Nama proses & $\begin{array}{c}\text { Kapasitas area } \\
\text { antrian produk (Palet) }\end{array}$ & $\begin{array}{l}\text { Jumlah kedatangan } \\
\text { produk (Palet/jam) }\end{array}$ & $\begin{array}{l}\text { Jumlah handling produk } \\
\text { (Palet/jam operator) }\end{array}$ \\
\hline${ }^{\mathrm{a}}$ Serah terima & 6 & 36 & 76 \\
\hline Racking & 20 & 154 & 50 \\
\hline Release & 3000 & 50 & 100 \\
\hline Transportasi ke arealoading & 30 & 100 & 25 \\
\hline Loading & 25 & 50 & 16 \\
\hline
\end{tabular}

a Jumlah kedatangan produk pada proses ini adalah input produk dari produksi ke gudang yang terdiri dari enam line produksi

Tabel 2. Hasil perhitungan performansi antrian dengan jumlah operator saat ini yang ditugaskan

\begin{tabular}{lcccc}
\hline \multicolumn{1}{c}{ Nama proses } & $\begin{array}{c}\text { Jumlah Operator } \\
\text { (Operator) }\end{array}$ & Wq (jam) & Lq (Palet) & Utilitas operator \\
\hline Serah Terima & 2 & 0 & 0 & 1,28 \\
Racking & 1 & 0,05 & 6 & 0,23 \\
Release & 1 & 0,01 & 0 & 2,4 \\
Transportasi ke area loading & 2 & 0,08 & 7 & 0,5 \\
Loading & 2 & 0,24 & 10 & 1,75 \\
\hline
\end{tabular}

Berdasarkan tabel diatas terlihat bahwa perhitungan utilitas operator pada proses racking, transportasi ke area loading, dan loading menghasilkan angka lebih dari satu. Menurut Cook (2009) utilitas dalam teori antrian adalah perbandingan antara kedatangan dan pelayanan produk untuk setiap fasilitas pelayanan.

Utilitas diartikan perbandingan antara aktual output dengan kapasitas maksimum output yang mampu dihasilkan sistem, sehingga utilitas juga dapat diartikan pemanfaatan atau penggunaan suatu sistem. Cook (2009) menjelaskan bahwa jika utilitas suatu sistem lebih dari $1(100 \%)$ maka dapat diartikan input yang dilakukan ke sistem lebih cepat dibandingkan kemampuan menghasilkan output. Area sistem akan menampung input sistem melebihi kapasitas maksimalnya sehingga menyebabkan bottleneck. Utilisasi kurang dari 1 mengindikasikan bahwa area penampungan input sistem (line) akan stabil dan menuju ke kondisi steady-state. Bottleneck adalah suatu kondisi dimana sistem menghasilkan output lebih sedikit dibandingkan laju input ke dalam sistem dengan area antrian input proses terbatas. Bottleneck menyebabkan aliran input terhenti dikarenakan proses sebelumnya tidak dapat beroperasi (Rouse, 2007). Berdasarkan pengertian tersebut dapat disimpulkan bahwa ketiga proses tersebut memiliki operator sibuk lebih besar dari pada operator yang ditugaskan. Tingkat kedatangan produk lebih besar dibandingkan kapasitas handling operator sehingga ketiga proses tersebut mengalami bottleneck.

Model sistem yang dirancang mampu mendeteksi kemungkinan terjadinya bottleneck berdasarkan tingkat kedatangan produk (arrival rate) dan kepergian produk (departure rate) pada sistem. Bottleneck didesain dengan aturan perkalian jumlah operator dengan departure rate untuk proses ke- $n$ akan menjadi arrival rate pada proses ke $\mathrm{n}+1$.
Deteksi bottleneck dilakukan dengan menambahkan warna merah pada sistem untuk proses yang mengalami kondisi bottleneck. Penggunaan warna ini untuk mempercepat pendeteksian bottleneck berdasarkan perhitungan performansi antrian. Bottleneck diperlihatkan oleh sistem untuk proses perhitungan performansi antrian dengan jumlah operator yang ditugaskan (current operator). Deteksi bottleneck digambarkan pada model berbasis komputer pada Gambar 7.

Model sistem yang dirancang mampu mendeteksi kemungkinan terjadinya bottleneck berdasarkan tingkat kedatangan produk (arrival rate) dan kepergian produk (departure rate) pada sistem. Bottleneck didesain dengan aturan perkalian jumlah operator dengan departure rate untuk proses ke- $n$ akan menjadi arrival rate pada proses ke $\mathrm{n}+1$. Deteksi bottleneck dilakukan dengan menambahkan warna merah pada sistem untuk proses yang mengalami kondisi bottleneck. Penggunaan warna ini untuk mempercepat pendeteksian bottleneck berdasarkan perhitungan performansi antrian. Bottleneck diperlihatkan oleh sistem untuk proses perhitungan performansi antrian dengan jumlah operator yang ditugaskan (current operator). Deteksi bottleneck digambarkan pada model berbasis komputer pada Gambar 7 dan Model sistem tidak mendeteksi adanya bottleneck berdasarkan jumlah operator usulan diatas seperti ditunjukkan pada Gambar 8.

\section{Pemodelan Sistem Pengambilan Pesanan pada Gudang Minuman Ringan}

Algoritma queue, stack dan color HSB menghasilkan model sistem yang menjawab kompleksitas permasalahan pada gudang finish good. Algortima antrian menghasilkan model sistem yang merepresentasikan area waiting lines seperti Gambar 9. 


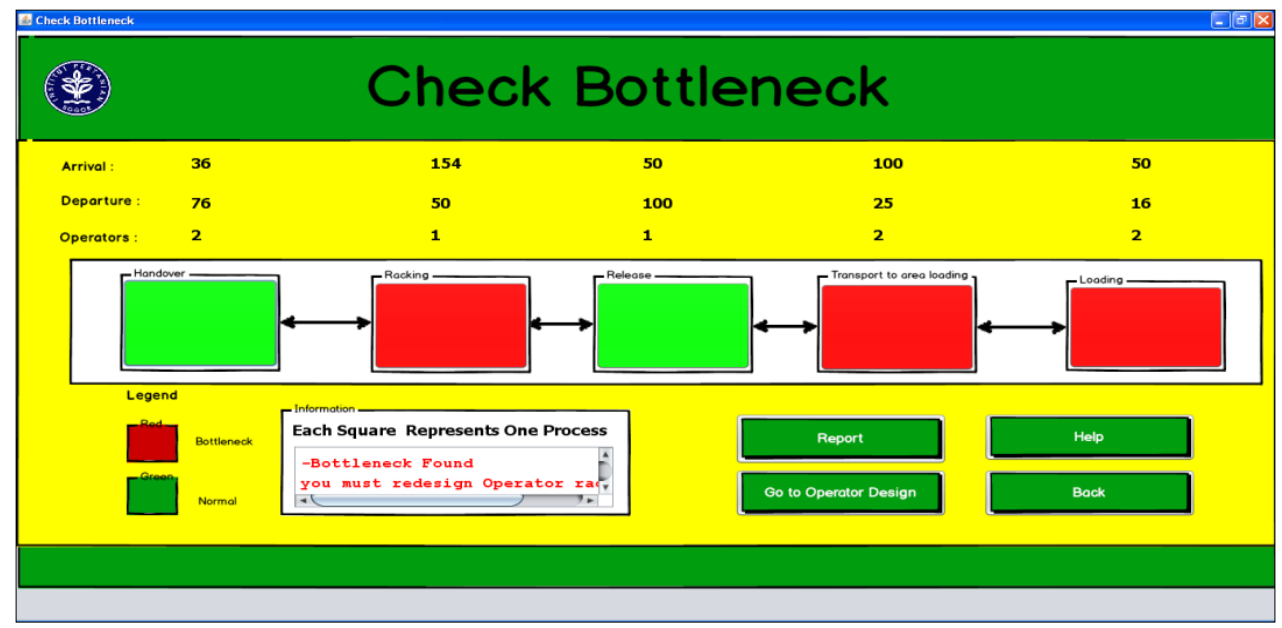

Gambar 7. Pengecekan bottleneck untuk rancangan operator saat ini (current operator) di gudang finish good

Tabel 3. Hasil perhitungan performansi antrian dengan jumlah operator usulan

\begin{tabular}{lcccc}
\hline \multicolumn{1}{c}{ Nama Proses } & $\begin{array}{c}\text { Jumlah Operator } \\
\text { (Operator) }\end{array}$ & $\begin{array}{c}\text { Wq } \\
(\mathbf{j a m})\end{array}$ & $\begin{array}{c}\text { Lq } \\
(\text { Palet })\end{array}$ & $\begin{array}{c}\text { Utilitas } \\
\text { operator }\end{array}$ \\
\hline Serah Terima & 1 & 0,01 & 1 & 0,54 \\
Racking & 2 & 0,03 & 2 & 0,76 \\
Release & 1 & 15,00 & 1499 & 1 \\
Transportasi ke area loading & 4 & 0,00 & 0 & 0,97 \\
Loading & 7 & 0,03 & 3 & 0,85 \\
\hline
\end{tabular}

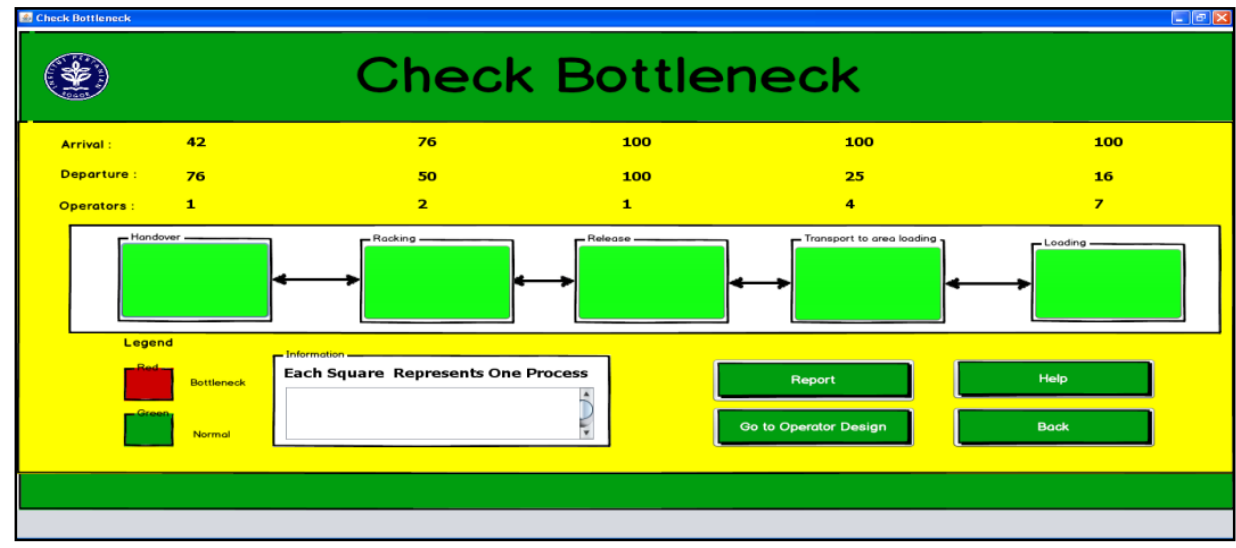

Gambar 8. Pengecekan bottleneck untuk jumlah operator usulan di gudang finish good menggunakan sistem Pineapple Logistic 1.0

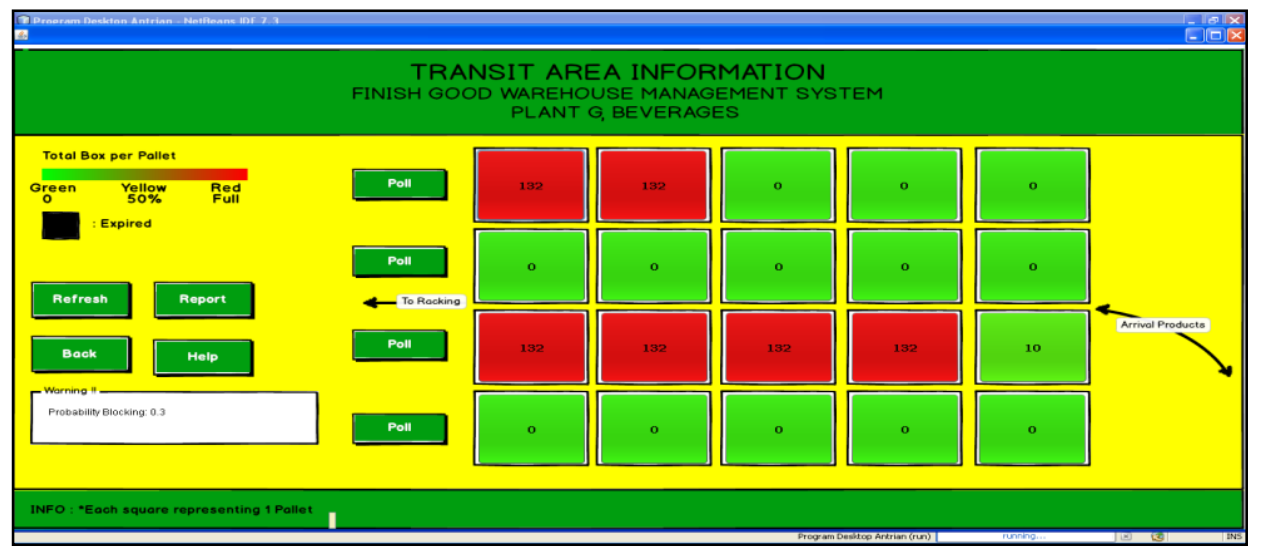

Gambar 9. Visualisasi hasil pemodelan antrian produk pada area waiting lines di gudang finish good berdasarkan konsep dan algoritma antrian pada sistem Pineapple Logistic 1.0 
Model algoritma tumpuk merepresentasikan rak drive-in dengan sistem rak LIFO. Representasi model rak drive-in pada sistem diperlihatkan pada Gambar 10. Warna hitam pada gambar diatas menunjukkan produk kadaluarsa. Aturan produk kadaluarsa adalah 7 bulan setelah produk diinput kedalam sistem. Warna menunjukkan hijau ke merah menunjukkan status tumpukan produk di dalam sistem, sedangkan untuk status produk digudang seperti inkubasi, release direpresentasikan dengan warna putih dan abu-abu seperti Gambar 11.

Produk dengan status release adalah produk yang telah lolos uji QC sehingga dapat dikeluarkan untuk proses transportasi ke gudang distributor. Produk dengan status tidak lolos uji QC (warna hitam) harus segera dikeluarkan, karena akan menyebabkan gudang menjadi penuh. Berdasarkan hal tersebut sistem dapat mendeteksi status produk secara cepat dan dapat menyelesaikan permasalahan sulitnya mendeteksi status produk karena sistem penyimpanan menggunakan rak drive-in.

\section{Peluang Produk Tidak Dapat Masuk ke dalam Sistem (Probability Blocking)}

Probability blocking merupakan kemampuan yang ditambahkan pada sistem Pineapple Logistic 1.0 untuk mengetahui kemungkinan produk tidak dapat masuk ke sistem (antrian atau rak) yang disebabkan kapasitas sistem penuh. Menurut Bhat (2008) probability blocking didefiniskan sebagai suatu kondisi pada model antrian dengan jumlah operator dan area antrian terbatas dimana produk tidak dapat masuk ke dalam sistem yang disebabkan sistem sibuk atau tidak mampu lagi menampung input. Pendekatan perhitungan dilakukan dengan metode transition diagram untuk bivariate markov process (Bhat, 2008).

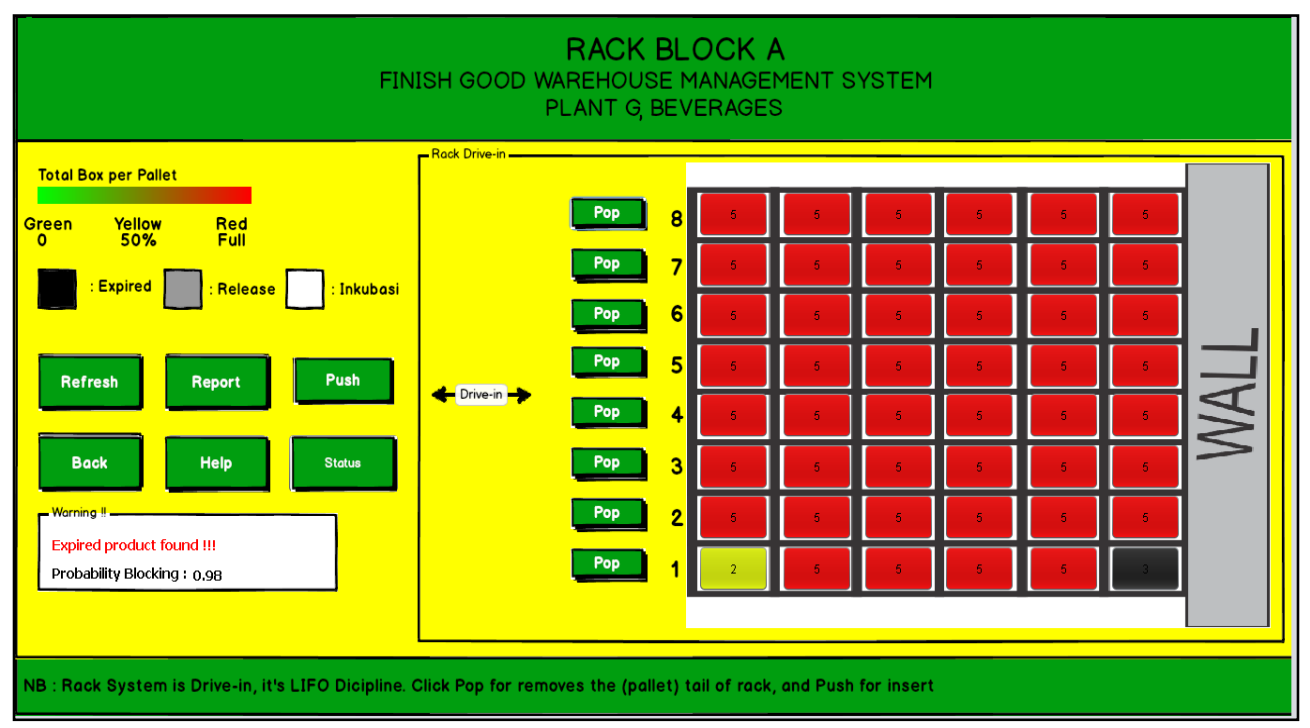

Gambar 10. Model sistem rak drive-in dan status tumpukan produk pada sistem Pineapple Logistic 1.0

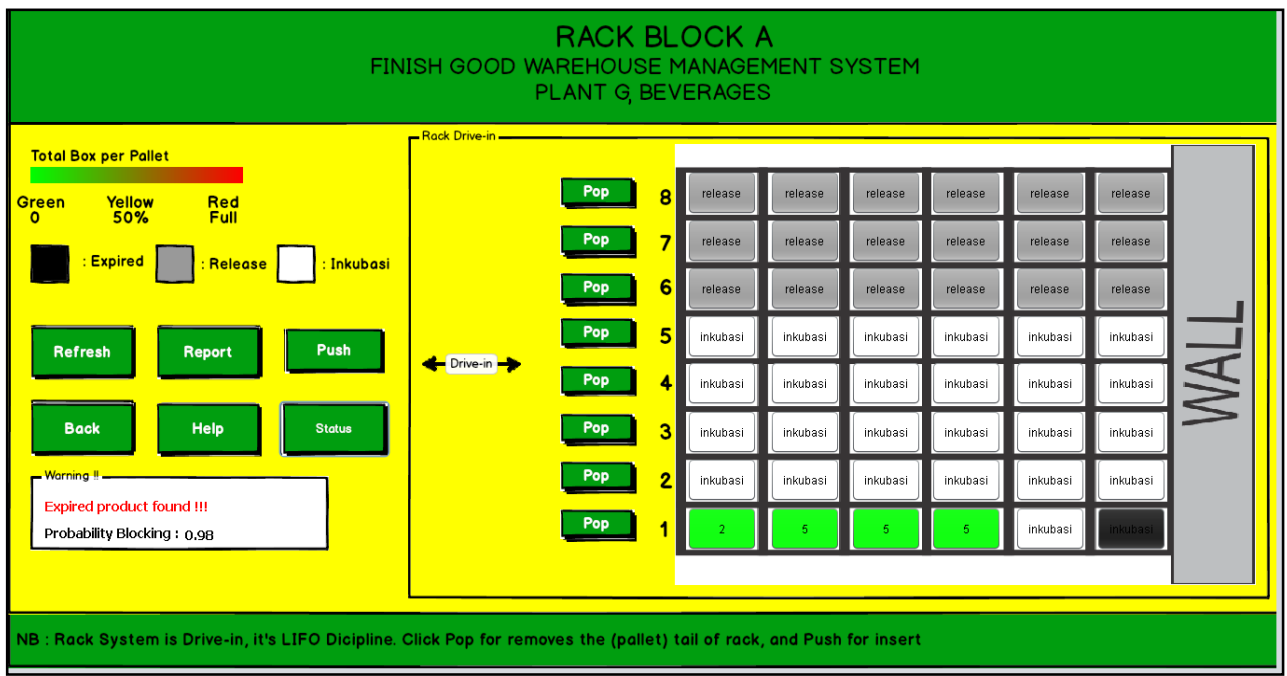

Gambar 11. Model sistem rak drive-in dan status produk pada sistem Pineapple Logistic 1.0 
Probability blocking pada model sistem pergudangan ini dilakukan dengan pendekatan penelusuran (searching). Teknik ini membandingan antara penelusuran status tumpukan palet pada rak dan area antrian dengan kapasitas maksimum yang dapat diproses sistem. Teknik penelusuran dilakukan dengan menggunakan bahasa query untuk mencari dan menghitung status tumpukan produk pada basisdata. Model perhitungannya didefinisikan sebagai berikut:

Probability blocking $=$

SearchingQuery ( status tumpukan produk pada data) Maksimum kapasitas sistem

Contoh hasil probability blocking diperlihatkan pada print screen tampilan sistem waiting lines 1 dengan jumlah produk mengantri pada sistem 792 kotak pada Gambar 12.

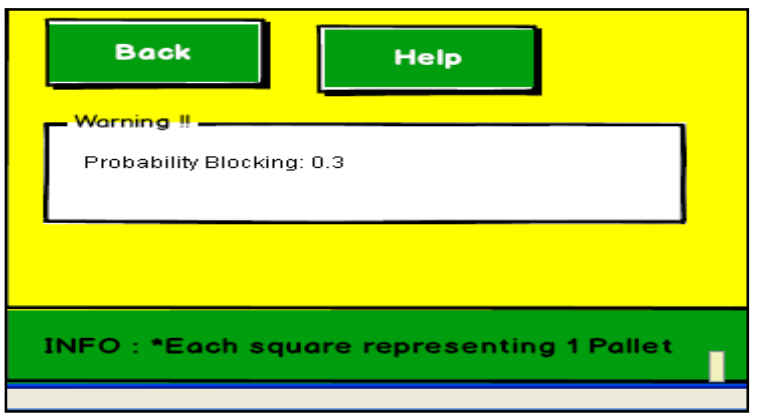

Gambar 12. Hasil identifikasi probability blocking pada sistem area waiting lines 1

\section{KESIMPULAN DAN SARAN}

\section{Kesimpulan}

Paper ini memodelkan sistem antrian pengambilan pesanan produk minuman ringan pada gudang dengan sistem rak drive-in dengan studi kasus pada minuman ringan olahan komoditas pertanian terkemas PET yang terdiri dari teh, kopi dan susu. Pendekatan yang digunakan adalah

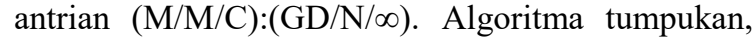
antrian, linkedlist, pewarnaan HSB (Hue, Saturation, Brightness) digunakan untuk merepresentasikan rak Drive-in, antrian produk, dan status produk pada gudang. Selanjutnya, model antrian tesebut diimplementasikan pada simulasi komputer menggunakan bahasa pemrograman java. Suatu studi kasus masalah industri nyata disajikan untuk menguji model yang dibangun. Berdasarkan studi kasus tersebut, model yang dibangun dapat menentukan kinerja gudang meliputi rendahnya kinerja pada proses racking, transportasi produk menuju area pembongkaran, dan proses pembongkaran produk untuk sejumlah operator yang saat ini ditugaskan serta adanya operator menganggur pada proses di gudang. Model juga dapat menentukan status produk berdasarkan hold, siap rilis dan kadaluarsa di gudang. Namun sistem dan model komputer yang dibangun pada penelitian ini memiliki kekuangan yaitu belum mempertimbangkan alokasi penyimpanan, rute, dan analisis belum mencakup keselurusah strategi operasional sistem pengambilan produk pada operasional penggudangan.

\section{Saran}

Riset ini adalah riset awalan untuk sistem pengambilan pesanan produk pada gudang minuman ringan dengan sistem rak drive-in. Riset-riset lanjutan harus dilakukan untuk menyempurnakan model meliputi alokasi penyimpanan, rute, pengambilan pesanan batch, serta implementasi dalam bentuk kasus yang lebih kompleks dan analisis yang lebih komprehensif terkait integrasi level operasional pergudangan.

\section{DAFTAR PUSTAKA}

Berglund P dan Batta R. 2012. Optimal placement of warehouse cross-aisles in a picker-to-part warehouse with class-based storage. IIE Transactions. 44(2):107-120.

Bertoli M, Gasale G, dan Serazzi G. 2009. JMT: performance engineering tools for system modeling. ACM SIGMETRICS Performance Evaluation Review, Volume 36 Issue 4, New York, US, ACM Pres.

Bhat N. 2008. An Introduction to Queueing Theory. Boston; Birkhouser

[BS] Balsamiq Studio. 2014. Balsamiq Mockups. Tersedia pada balsamiq.com/ products/mockups.

Cook JD. 2009. Server utilization. tersedia pada http://www.johndcook.com [8 Juni 2014].

Colebourne J. 2014 Joda-Time. Tersedia pada http://www.joda.org/joda-time/ [5 April 2014].

Cormen TH, Leiserson CE, Rivest RL, Stein C. 2009. Introduction to Algorithms, $3^{\text {ed }}$. Massachusetts: MIT Pers.

De Koster R, Le-Duc T, dan Roodbergen K J. 2007. Design and control of warehouse order picking: A literature review. European Journal of Operational Research. 182(2): 481-501.

Gademann N dan Velde S. 2005. Order batching to minimize total travel time in a parallel-aisle warehouse. IIE Transactions.37(1): 63-75.

Goetschalckx M dan Ashayeri J.1989. Classification and design of order picking. Logistics World. 2(2): 99-106.

[OC] Oracle Technology. 2013. Netbeans IDE 7.3. Tersedia pada https://netbeans.org/ community/releases/73/. [ 11 Juli 2013].

Pan JCH, Shih PH, Wu MH, Lin JH. 2016. A storage assignment heuristic method based 
on genetic algorithm for a pick-and-pass warehousing system. Computers \& Industrial Engineering. 81: 1-13.

Parikh PJ dan Meller RD. 2007. Modeling pick-face blocking in an order picking system. in iie annual conference. Proceedings (p. 866). Institute of Industrial and Systems Engineers (IISE).

Petersen CG dan Schmenner RW. 1999. An evaluation of routing and volume-based storage policies in an order picking operation. Decision Sciences. 30(2): 481501.

Rouse. 2007. Definition of Bottleneck. Tersedia pada http://searchenterprisewan. techtarget.com/definition/bottleneck [8 Juni 2014].
Seidler K dan Vogelgesang K. 2014. Apache FriendXAMPP.

Tersedia

pada http://apachefriend.org. [25 Maret 2014].

Taha AH. 2007. Operation Research. $7^{\mathrm{Ed}} . \mathrm{USA}$; Pearson Prentice Hall.

Tompkins JA, White JA, Bozer YA, Tanchoco JMA. 2010. Facilities Planning. New York: John Wiley \& Sons.

Yang P, Miao L, Xue Z, Qin L. 2015. An integrated optimization of location assignment and storage/retrieval scheduling in multi-shuttle automated storage/retrieval systems. Journal of Intelligent Manufacturing. 26(6):1145-1159. 